\title{
Marine Genetic Resources: a Practical Legal Approach to Stimulate Research, Conservation and Benefit Sharing
}

\author{
Morten Walløe Tvedt
}

In September 2018, the negotiation of a new international legally binding instrument (ILBI) for the Area Beyond National Jurisdiction (ABNJ) took the first really concrete steps under the United Nations Convention on the Law of the Sea $\left(\mathrm{UNCLOS}^{1}\right) .^{2}$ Prior to the General Assembly establishing this Intergovernmental Committee there have been meetings in a Preparatory Committee and Ad Hoc Working group, dating back more than a decade. ${ }^{3}$ The second meeting of the Intergovernmental Committee spent, at its meeting in March-April 2019, two and a half days discussing the role of marine genetic resources (MGR). In the working document 'Chair's streamlined non-paper on elements of a draft text of an international legally-binding instrument' that might be the first textual step towards what might be a protocol to UNCLOS, MGR are allocated six pages drawing on experiences of other regulations of genetic resources. ${ }^{4}$

There are a number of special regulatory and factual features for marine genetic resources that cannot be copy-pasted from any of the existing regimes

* The research behind this chapter is conducted under the project BiosPolar funded by the Norwegian Research Council "Legal frameworks for bioprospecting and bio-innovation in Polar Regions (BiosPolar)" (Project number 257631/E10).

1 United Nations Convention on the Law of the Sea, 1833 Un TS 3, adopted on 10 December 1982.

2 According to the General Assembly resolution 72/249 of 24 December 2017.

3 The Ad Hoc was established by resolution of the United Nations General Assembly, Oceans and the Law of the Sea (A/RES/59/24, 2004). For more information about the early steps, see https://www.un.org/Depts/los/biodiversityworkinggroup/biodiversityworkinggroup.htm.

4 https://www.un.org/depts/los/biodiversity/prepcom_files/Chairs_streamlined_non-paper_ to_delegations.pdf Leary focuses on the many topics on which there is yet no consensus, in Leary, D. (2019) Agreeing to disagree on what we have or have not agreed on: The current state of play of the BвNJ negotiations on the status of marine genetic resources in areas beyond national jurisdiction, Marine Policy. Volume 99, pp. 21-29. 
on Access and Benefit Sharing (ABS). 5 The ABs system of Convention of Biological Diversity (CBD) or its Nagoya Protocol (NP $)^{6}$ does not apply directly to $\mathrm{ABNJ} .{ }^{7}$ One obvious feature is the lack of a state with sovereign rights to and jurisdiction over marine genetic resources. Consequently, there are no existing institutions to grant access, provide a prior informed consent and be the counterpart in a contract.

Even if the 'Chair's non-paper' from 2019 is built on definitions and concepts from existing ABS regimes, they are not legally binding in the ABNJ. Thus, a new instrument in the ABNJ can choose other approaches. The UNCLOS itself takes both a resource approach and an activity approach in its regulation. ${ }^{8}$ The resource approach appears in the regulation of 'living resources'. The concept of 'living resources' focuses rather on bulk harvest and is not geared towards 'marine genetic resources'. Rules concerning 'marine scientific research' constitute the most relevant activity for the topic here. There is some overlap between MRS and bioprospecting as both cover types of scientific research, whereas bioprospecting is broader. ${ }^{9}$ Since neither the marine genetic resources nor the activity bioprospecting are regulated for the high seas and deep seabed, it must be concluded that there is regulatory room for the negotiations.

5 The EU suggested in 2008 taking the multilateral mechanism under the International Treaty on Plant Genetic Resources for Food and Agriculture (ITPG RFA, International Treaty on Plant Genetic Resources for Food and Agriculture, 2400 UNTS 303, adopted on 3 November 2001) as a reference point for the discussions. Though most Parties welcomed the proposal (Broggiato, A. (2008) 'Marine Biological Diversity in Areas Beyond National Jurisdiction', Environmental Law and Policy, 38(4), 182-188, at p. 186) the Plant Treaty is made for facilitating plant breeding which a different technical field. Differences are also highlighted by Leary, explaining that regime is tailored for mineral resource exploitation and does not answer how benefit sharing would be done when inventions are patent protected (Leary, D. (2009) 'International Law and the Genetic Resources of the Deep Sea', in Vidas, D. (ed.) Law, Technology and Science for Oceans in Globalisation: IUU Fishing, Oil Pollution, Bioprospecting, Outer Continental shelf. Martinus Nijhoff, Leiden, pp. 353-69, at p. 366).

6 Convention on Biological Diversity, 1760 UnTs 79, adopted on 5 June 1992, article 15. Nagoya Protocol on Access to Genetic Resources and the Fair and Equitable Sharing of Benefits Arising from their Utilization to the Convention on Biological Diversity, adopted on 29 October 2010.

7 Its provisions apply in relation to each contracting party to areas within national jurisdiction and may only be extended to ABNJ as a result of flag state jurisdiction. See ibid., article 4(a) and (b). See as well Chapter 11 of this book, Tullio Scovazzi, 'The Rights to Genetic Resources beyond National Jurisdiction: Challenges for the ongoing Negotiations at the United Nations'.

8 Jørem, A. and M.W. Tvedt (2014). "Bioprospecting in the High Seas: Existing Rights and Obligations in View of a New Legal Regime for Marine Areas beyond National Jurisdiction." The International Journal of Marine and Coastal Law 29: 321-343, at p. 324 sig.

9 Jørem and Tvedt conducts a thorough study of these concepts, see ibid., pp. 327-333. 
The basic idea of introducing regulation of any aspects of marine genetic resources is to change the behaviour of researchers and commercial firms using the resources or conducting the activities. Meanwhile, Parties to UNCLOS are states. If an international legally binding instrument is to have any potential to bind private parties, it is not enough to address the questions in international law; the content of a new instrument must be designed in a manner possible to be implemented by and enforced on private legal persons. One goal of this chapter is to explore options for how to make an ABS system for ABNJ legally binding on users. This means that all suggestions are tested against whether it would be possible to oblige private parties to a system of both access and benefit sharing.

The ultimate objective of this chapter is to identify the legal elements required for a functional model of a binding access and benefit sharing system that also promotes global research and development based on marine genetic resources.

This chapter contributes to the debate by identifying the legal solutions to the system being proposed (Section 2). After having looked at the practical system, Section 3 reviews the legal tools that are already available without amending the UNCLOS, and, based on a review of the bioprospecting activities envisaged (Section 4), review the set of key obligations related to registering of samples and depository in a repository (Section 5). The chapter ends with a discussion of the necessary institutional framework (Section 6), before summarizing the solution proposed (Section 7).

\section{Short Description of the Proposed 'Realistic and Functional' System for ABS}

There seems to be a growing consensus among legal scholars that an ABS regime needs to include States without capacity to conduct cruises themselves by making samples and information available to a broader audience than to the collector alone. ${ }^{10}$ This approach to a regulatory system also draws moral legitimacy from distributive theories, as the Theory of Justice. ${ }^{11}$ The essence of

\footnotetext{
10 For one of the most recent proposals: Broggiato, A. (2018), Mare Geneticum: Balancing Governance of Marine Genetic Resources in International Waters, The International Journal of Marine and Coastal Law 33, doi 10.1163/15718085-13310030, pp. 3-33, about the rationale at pp. 10-12 and 14-16.

11 This could be based on a morally based fairness argument; however, it has been conceptualized in different ways. Fairness, a core perspective, is that of Rawls's, as described in A Theory of Justice (Rawls, J. (1999) A Theory of Justice: Revised Edition, Belknapp
} 
this conception of fairness is that any new legal tool must contribute at least so that the worse off be put in a slightly better position.

Increasingly, it is suggested making samples available by storing them in ex situ conservation conditions sites. ${ }^{12}$ Accessible collections can ensure sustainable use, ${ }^{13}$ encourage research, ${ }^{14}$ and lead to the development of commercially interesting products or processes. ${ }^{15}$ The establishment of just one global repository would not be a practical solution since it will by necessity be very far from at least some of the oceans where collections take place. Therefore, a distributed global system repositories with branches bound together in a global network is probably the only practical solution.

One practical idea for governing MGR including both monetary and non-monetary benefit-sharing was developed by Tvedt and Jørem in $2013 .{ }^{16}$ In

Press, Cambridge (MA)). Although Rawls did not himself apply his theory to international issues without modification (Rawls, J. (1993) 'The Law of the Peoples', Critical Inquiry, 20(1), 36-68, pp. 36-68; Rawls, 1999, pp. 331-5). UNCLOS, preamble, paragraph 5 . On the justice of using genetic resources, see also D. Schroeder, and T. Pogge, 'Justice and the Convention on Biological Diversity', Ethics and International Affairs, (2009) 23(3), 267-80. The link to fairness has been contested, see R.D. Simpson, 'Biodiversity Prospecting: Shopping the Wild Is Not the Key to Conservation', Resources, (1997) 126, $12-5$.

12 СвD, Article 2, paragraph 13 defines in situ conservation as "the conservation of ecosystems and natural habitats and the maintenance and recovery of viable populations of species in their natural surroundings [...]". Ibid., Article 2, paragraph 8: Ex situ conservation is the "conservation of components of biological diversity outside their natural habitats".

13 Drawing the lines back to sustainable development understood as "limitations imposed by the state of technology and social organization on the environment's ability to meet present and future needs." in World Commission on Environment and Development, Report of the World Commission on Environment and Development: Our Common Future (Annex to document A/42/427, 1987), part IV, paragraph 1. See also P. Sands, Principles of International Environmental Law (Cambridge University Press, Cambridge, 2003), p. 253.

14 This is a utilitarian argument of taking advantage of biological material. See e.g. Ad Hoc Open-Ended Informal Working Group, Letter dated ${ }_{15}$ May 2008 from the Co-Chairpersons of the Ad-Hoc Open-Ended Informal Working Group to Study Issues Relating to the Conservation of Marine Biological Diversity in Areas Beyond National Jurisdiction to the President of the General Assembly (A/63/79), paragraphs 6 and 10. See also Harden-Davies, H. (2017) Deep-sea genetic resources: New frontiers for science and stewardship in areas beyond national jurisdiction, Deep Sea Research Part II: Topical Studies in Oceanography. Volume 137. March 2017, pp. 504-513. On the effects of the economic downturn for biotechnology, see G. Giovannetti, and G. Jaggi, Beyond Borders: Global Biotechnology Report 2012, (Ernst \& Young, 2012), n.p., pp. 25-39.

15 Tiller, R. et al., (2019), The once and future treaty: Towards a new regime for biodiversity in areas beyond national jurisdiction, Marine Policy. Volume 99, pp. 239-242.

16 Tvedt, Morten Walløe and Ane E. Jørem. "Bioprospecting in the High Seas: Regulatory Options for Benefit Sharing" in Journal of World Intellectual Property 16 (2013) 3-4. 
the 2018 article Mare Geneticum, similar ideas were described by Broggiato and Vanagt et al. ${ }^{17}$ The remainder of this chapter will scrutinize the legal requirements and possibilities of such a factual system that strike the balance between open access and commercial interests in marine genetic resources.

Such an ABS system builds on the successive steps of access, deposit, utilisation and then creation of benefit sharing. Broggiato et al. elaborate further on the manner to address those successive steps and suggest a list of eight actions, as described below. Their analysis is very normative in arguing how the system should be set up. Although this list has the benefit of providing an outline of how an ABS system could set up in the ABNJ, it remains vague in terms of legally enforceable elements. They merely mention that 'these conditions will need to be encoded into legal obligations' suggesting a clickwrap. ${ }^{18}$ Given that each of these steps entails different legal challenges, for each of the actions identified, the present author has indicated in the second column the related legal aspects that will need to be addressed.

The elements in the right column will be further developed in the next sections, with the aim of transposing the different actions on the list into legally

TABLE 11.1

Proposed steps in Broggiato et al. Required legal action

Submit and register plans for research To be binding on the users, this needs to be or bioprospecting (at pp. 17-18) an obligation in national law based on flag State jurisdiction

Register the material sampled in the Can be imposed either in national law or in "OPEN" system a contract entered into at an earlier point of time (otherwise voluntary)

Deposit samples of what has been The flag State can set this as a criterion collected (at p. 22) before a cruise, for this to be binding after the cruise/collection has ended, it would have to have been translated into a contractual obligation.

pp. 150-167 and presentation by Tvedt at FNI side-event 23th August 2013.

17 Broggiato, A. (2018), Mare Geneticum: Balancing Governance of Marine Genetic Resources in International Waters, The International Journal of Marine and Coastal Law 33, doi 10.1163/15718085-13310030, pp. 3-33. 
TABLE 11.1 (cont.)

\section{Proposed steps in Broggiato et al. Required legal action}

Research according to the plans submitted initially (at pp. 17-18)

Update information in the data base when transferring to subsequent user

Embargo period for others or the payment of exclusivity fee (at p. 22)

Commercialisation (at pp. 22-24)
Any submitted plans are non-binding unless that are made binding by a contract.

Theoretically possible to regulate in a contract, but there are considerable enforcement challenges.

The collection could regulate the criteria for when others can use the material in its criteria for receiving material.

Other types of legislation than that of bioprospecting, like patent law or that of product approval, come into play. A contract must set these rules before bioprospecting starts.

A national law of users imposing an obligation of payment or a contractual obligation. gross sales of a product (at pp. 22-24 and 28-29)

binding obligations. Indeed, in their discussion, Broggiato et al. presuppose legally binding criteria, without discussing the legal tools for making the respective steps binding on the user. If these steps are not turned into binding obligations on the users (and not only in international law) then the system will end up becoming voluntary on the users. To ensure users change their behaviour, however, the question of how to make obligations legally binding and enforceable must be answered. Any lack of means to enforce obligations renders the system to be voluntary and therefore not legally functionalig and enforceable.2o This chapter takes the body of proposals as a point of departure and discusses what would be required to make their proposals into a legally workable system.

A central contribution with the present chapter is to reflect on the legal tools that could introduce regulation on marine genetic resources in the $\mathrm{ABNJ}$,

19 Functionality of ABS is discussed by Tvedt (2017) in Beyond Nagoya: Towards a Legally Functional System of Access and Benefit-sharing in Global Governance of Genetic Resources Access and Benefit Sharing after the Nagoya Protocol. Edited by Sebastian Oberthür and G. Kristin Rosendal. New York, Routledge, 2014. pp. 158-178.

$20 \quad$ Young, T., \& Tvedt, M. (2017). "Preface". In Drafting Successful Access and Benefit-sharing Contracts. Leiden, The Netherlands: Brill | Nijhoff. 
without creating heavy regulatory burdens or bureaucratic procedures for the users. Broggiato et al. set out as an overall virtues: " $[\mathrm{t}]$ o reduce the transaction costs and to maximize predictability, which are necessary to attract investments from the private sector, a fixed percentage would be preferable over a case-by-case negotiation." ${ }^{21}$ It is a general criticism against СвD and NP that the ABS system does not meet these criteria. The concept of benefit sharing is inspired by the CBD and NP. MGR-issues in the ABNJ do not necessarily need to be resolved in an identical manner, since there is no sovereign rights of states beyond the national jurisdiction. A major challenge is to embed a system in existing rules for the $\mathrm{ABNJ}$ while avoiding general $\mathrm{ABS}$ challenges.

\section{Legal Tools Available without Amending the UNCLOS}

Since amending an existing international treaty or convention is a challenging task, this chapter is taking a pragmatic approach by rather proposing legally binding tools and elements that do not require the existing text of UNCLOS to be changed. This chapter takes the existing international law for granted and rather identifies how the Intergovernmental Committee can adapt new tools supplementing the existing ones.

There is an underlying tension between the freedoms of the high seas and the competence of the flag state to apply regulations. One approach to impose obligation on private persons is by using the flag state jurisdiction combined with a contractual obligation on the users of MGR at the point of time of accessing the material.

There are some articles in UNCLOS that are particularly relevant to bear in mind in this discussion: Article 118 of UNCLOS deals with the Cooperation of States in the conservation and management of living resources. It reads as follows:

States shall cooperate with each other in the conservation and management of living resources in the areas of the high seas. States whose nationals exploit identical living resources, or different living resources in the same area, shall enter into negotiations with a view to taking the

21 Broggiato, A. et al. (2018), Mare Geneticum, at p. 10. It is interesting to observe that their proposal and the general guideline for their discussion was proposed by some countries in Ad Hoc Open-ended Informal Working Group, Letter Dated 30 June 2011 from the Co-Chairs of the Ad Hoc Open-ended Informal Working Group to the President of the General Assembly (A/66/119, 2011), paragraph 6. 
measures necessary for the conservation of the living resources concerned. $[\ldots]$

Article 118 establishes an obligation to collaborate for conservation and management of living resources. Flag State jurisdiction can be used as a legal tool in the UNCLOS in order to implement obligations on the users. The system for making samples available can be seen as a way different countries can work together.

Another relevant provisions is UNCLOS Article 263 on "Responsibility and liability", which establishes responsibility on States for their nationals. Article 263 provides as follows:

1. States and competent international organizations shall be responsible for ensuring that marine scientific research, whether undertaken by them or on their behalf, is conducted in accordance with this Convention.

2. States and competent international organizations shall be responsible and liable for the easures they take in contravention of this Convention in respect of marine scientific research conducted by other States, their natural or juridical persons or by competent international organizations, and shall provide compensation for damage resulting from such measures.

3. States and competent international organizations shall be responsible and liable pursuant to article 235 for damage caused by pollution of the marine environment arising out of marine scientific research undertaken by them or on their behalf.

The responsibility of States to control 'marine scientific research' can be used as a model for them also to control their national when conducting bioprospecting. Drawing on this obligation, the possibility of regulating in greater detail how governments must apply their flag state jurisdiction, is not a new idea when it comes to changing the behaviour of their citizens.

\section{Bioprospecting Activities on the High Seas and in the Area}

Bioprospecting is defined as the search for new and useful biological and genetic resources. Activities are taking place both on the high seas and potentially 
in the deep seabed. The research for and exploitation of MGR in the Area ${ }^{22}$ have generated more debate and a more substantial body of literature ${ }^{23}$ than those on the high seas. Expeditions for bioprospecting are often referred to as "cruises", fulfilling a range of different purposes, including population studies, taxonomic mapping of species occurrence, commercially oriented exploration and systematic collection of samples. One first step in a potential ABs system is to monitor and register the activities. In that context, the central question is to establish how a legally binding regime could make a register mandatory.

In that respect, and because the concept of "genetic resources" is not defined in UNCLOS, it could be useful to look at how the Convention deals with other related activities. Two main activities in the area which are declared as freedoms are "fishing" (Art. 87.1.e, UNCLOS) and "marine scientific research" (Art. 256 and 257, UNCLOS). Fishing has a very different purpose than bioprospecting and the rules regulating fishing are not suited to be applied directly; especially since fishing has large quantities of one or specific species as a goal, whereas bioprospecting generally requires small quantities. ${ }^{24}$

To answer the question make a register mandatory under the Convention, it is necessary to look at the link between an obligation to register and the existing right in the High Seas or the deep seabed. According to respectively Articles 256 and 257 of UNCLOS, which both deal with marine scientific research, "[a]ll States, irrespective of their geographical location, and competent international organizations have the right, in conformity with this Convention, to conduct marine scientific research in the water column beyond the limits of the exclusive economic zone." Article 257 refers instead to Part XI of the Convention and to the Area.

22 The Area is the "seabed and the ocean floor and the subsoil thereof beyond national jurisdiction". UNCLOS, article 1(1).

23 See e.g. L. Glowka, 'The Deepest of Ironies: Genetic Resources, Marine Scientific Research, and the Area' (1996) Ocean Yearbook, 12, 154-78; A.G. Oude Elferink, 'The Regime of the Area: Delineating the Scope of Application of the Common Heritage Principle and Freedom of the High Seas', (2007) The International Journal of Marine and Coastal Law, 22(1), 143-75; N. Matz-Lück, 'The Concept of the Common Heritage of Mankind', in E.J. Molenaar, and A.G. Oude Elferink, (eds) The International Legal Regime of Areas Beyond National Jurisdiction: Current and Future Developments (Martinus Nijhoff, Leiden, 2010), pp. 61-75; T. Scovazzi, 'The Seabed Beyond the Limits of National Jurisdiction: General and Institutional Aspects', in Oude Elferink, A.G. and Molenaar, E.J. (eds) The International Legal Regime of Areas Beyond National Jurisdiction: Current and Future Developments (Martinus Nijhoff, Leiden, 2010), pp. 43-6o.

24 See Jørem, A. and M.W. Tvedt (2014). "Bioprospecting in the High Seas: Existing Rights and Obligations in View of a New Legal Regime for Marine Areas beyond National Jurisdiction.” The International Journal of Marine and Coastal Law 29: 321-343, at pp. 325-327. 
The detailed meaning of 'marine scientific research' as referred to in those articles is not defined in the Convention. ${ }^{25}$ Because it is unlikely that the wording of Articles 256 and 257 will be modified and because this chapter intends to avoid the need for amendment, a possible solution would be to subsume the obligation to register under these rules. These articles allocate rights to States and not directly to private parties. The wording here does not include any obligation to register, nor does it include an obligation to register 'marine scientific research' in a clearing-house register for control purposes.

To compare, the argument has often been raised in CBD-related discussions that 'non-commercial' uses shall be left unregulated and that the regulatory obligation only kicks in when use turns 'commercial'. This dichotomy depends on the intention of the user at the point of time of initiating a cruise, which may be difficult to assess. The objectively manifest activity, however, is "collecting samples" both for non-commercial and commercial purposes. It is not possible to establish externally verifiable criteria to assess whether the intention is non-commercial or commercial, and therefore this dichotomy cannot be used as a legal criterion triggering different sets of obligations.

Regulating bioprospecting in the $\mathrm{ABNJ}$ will be less bureaucratic and create more legal certainty if the activity of 'collecting samples' is regulated regardless of the subjective intentions of the collector. The proposal here is that the actors at this point in time sign a standard contract. Such a contract needs to regulate scenarios for both non-commercial activities along with commercial ones. From the user-perspective, it is less bureaucratic to sign one contract regardless of what he has in mind when carrying out the collection. The counter-argument would be that such a contract would include a number of obligations that do not kick in since the trigger-point is never reached. This is not a unique situation in bioprospecting, since e.g. software contracts set out a large number of clauses that are not even observed. The rest of this article will show solutions for a one-size-fits-all standard contract and outline different aspects to be included in it to safeguard the different elements from collection, through research and utilisation to the creation of economic gains, identifying needs from the legislative level and need for preparing institutions.

To implement a rule requiring registration by users would require flag States to impose an obligation on their research vessels (and vessels in general since they could be potential bioprospectors) to register their activities. Since it is not unusual for researchers from different nations to participate on a cruise

25 See Jørem, A. and M.W. Tvedt (2014). "Bioprospecting in the High Seas: Existing Rights and Obligations in View of a New Legal Regime for Marine Areas beyond National Jurisdiction." The International Journal of Marine and Coastal Law 29: 321-343., pp. 327. 
and in one vessel, the regulatory requirement must be put on the flag State responsible for all activities on board regardless of the nationality of the individual researchers on board. To make such an obligation binding the international regime will have to establish an obligation on the flag States targeting how they regulate the participants in the cruises on vessels sailing their flag. Thus, an international regime needs to oblige the contracting states to require the user to enter into the standard contract, foreseeing and providing solutions for all most relevant potential scenarios.

During and after the collecting activities have ended, two actions should be required: first, to register the sample taken and, second, deposit a duplicate or copy-sample of the biological material in a global repository system.

Grieber suggested as recently as 2011 that "One approach to non-monetary benefit sharing would be to establish a common pool of biological material retrieved from the high seas." ${ }^{26}$ Further, Tvedt and Jørem noted that: "Such a common pool collection model for samples from the high seas would entail a continuum of marine resources being open to all."27 The basic idea behind this option is to spur innovation by maintaining the material available for research and development for a greater scientific and perhaps also commercial audience than those with the financial resources to bioprospect in the high seas. ${ }^{28}$ An example of ex situ conservation is keeping reproductive material in collections as a resource for research, or for reintroduction of endangered species

26 Greiber, 2011, pp. 36, 46-7. On the development of the open source movement, see e.g. Mandrusiak, L. (2010) 'Balancing Open Source Paradigms and Traditional Intellectual Property Models to Optimize Innovation', Maine Law Review, 63(1), pp. 313-6. See e.g. E.C. Kamau, and G. Winter, (eds) Common Pools of Genetic Resources: Equity and Innovation in International Biodiversity Law, (Routledge, London, 2013). See e.g. A. Broggiato, 'Marine Genetic Resources Beyond National Jurisdiction - Coordination and Harmonisation of Governance Regimes', Environmental Policy and Law, (2011) 41(1), p. 36; also D. Leary, 'International Law and the Genetic Resources of the Deep Sea', in Vidas, D. (ed.) Law, Technology and Science for Oceans in Globalisation: IUU Fishing, Oil Pollution, Bioprospecting, Outer Continental shelf. (Martinus Nijhoff, Leiden, 2009) p. 362.

27 Jørem, A. and M.W. Tvedt (2014). "Bioprospecting in the High Seas: Existing Rights and Obligations in View of a New Legal Regime for Marine Areas beyond National Jurisdiction." The International Journal of Marine and Coastal Law 29: 321-343.

28 Jørem, A. and M.W. Tvedt (2014). "Bioprospecting in the High Seas: Existing Rights and Obligations in View of a New Legal Regime for Marine Areas beyond National Jurisdiction." The International Journal of Marine and Coastal Law 29: 321-343. 
into the wild. Other rational for repositories is to make the samples available for research and product-development by a broader audience. ${ }^{29}$

Establishing a common pool of MGR makes it necessary to discuss and clarify legal questions related to the pool itself and the degree of commonness of the material therein. Tvedt and Schei have identified five legal and practical topics to clarify for repositories. ${ }^{30}$ The following sections develop three topics from a practical-legal perspective: the subject matter to be included in such a common pool (Section 5.1); the conditions for exclusivity for the depository (Section 5.2); and, the definition of the access rights to the material in the respository and limitations to such rights by others (Section 5.3). A final issue deals with the possibility of imposing obligations related to transfer (Section 5.4).

\section{1}

The Subject Matter Deposited in the Repository

Concerning the subject matter to be included at the repository there is a limited number of possibilities. Examples of biological material that can be kept in a duplicate collection are living specimens from micro-organisms to higher organisms; biological material that is not living but still intact as an organism; biological material in alternate form; or, any type of dried material. This ranges from aquarium-style living samples to highly prepared laboratory samples of biological material. These different biological conditions or formats of the material will require different forms for storage capacity and will open for different types of uses.

The most relevant point of time to ask for these samples/accessions to the repository is when the cruise comes to an end. At that moment, a legal regulation is likely to have less effect since a private person has the material in hand. If then no strings were attached to the material when it was collected, it is difficult to attach new legal regulations to the material. A contract entered into at the moment of entering upon the cruise could require duplicates in any of these conditions along with passport data to be left with the repository.

29 For a comparison of impacts of seabed mining and fossil fuel extraction compared to bioprospecting, see E., Ramirez-Llodra, P.A., Tyler, M.C., Baker, O.A. Bergstad, and M.A. Clark, 'Man and the Last Great Wilderness: Human Impact on the Deep Sea', (2011) PLoS One, 6(7), pp. 11-5.

30 Tvedt, $\mathrm{M}$ and Schei, P.J., 2009, The legal status for MARBANK and other marine biobanks in Norway, FNI Report 6/2009 identify the following legal questions: defining the material or information included in the pool; regulate the legal position of the depositor; the management of the pool itself; the legal position of the user of material taken out of the pool; and finally questions regarding ownership of the collection itself. 
From any of these biological samples, different new expressions of the biological material can be produced: taxonomic information; ready-made assays; biochemical composition; DNA sequencing; digital sequence data; screening of the entire genome; developing metagenome and synthesized new molecules copying those found in nature. Typically, these new abstractions from the original samples are steps in research and development activities. A contract agreed to at the point of leaving for a cruise of collection needs also to regulate aspects relating to any information, knowledge or use of these biological subject matters. ${ }^{31}$ Later than prior to collection, a user has no incentive to enter into a contract or undertake any obligations restricting the right to the sampled material. Any contractual obligation that is not included into the initial contract becomes voluntary. This situation is parallel to the Plant Treaty that establishes a system for access to plant genetic resources on the terms and conditions set out in its Standard Material Transfer Agreement. (There are weaknesses with the SMTA and it is currently undergoing a renegotiation.) Common for the two situations is that any obligation that is not included in the contract tends to be voluntary for the user. A first lesson to be drawn here is that all aspects must be regulated in the first contract.

A next important lesson is that since the UNCLOS is not using the terminology 'genetic resources', the new international legally binding instrument can be regulating the subject matter (res) of the obligations in a more precise manner. The term 'genetic resources' as it is defined in the CBD entails considerable difficulties for a contract. ${ }^{32}$ If the ILBI copies those definitions rather than being more specific in what a contract regulates, the same lack of clarity as we see in the $\mathrm{CBD} / \mathrm{NP}$ today will be reproduced for marine resources. The ILBI needs to ensure it is does not become outdated even before its signing, and could be more technology-neutral is it leaves flexibility to the standard contract to define the subject matters regulated by the contractual obligations. The important lesson to learn from contract law concerning the obligation to share any sample, information or knowledge is that the contract needs to be precise and that the language in the $\mathrm{CBD} / \mathrm{NP}$ is not necessarily suited for the purpose of contract language.

$31 \quad$ I.e. "describing biological processes or experiments that are simulated by a computer program", A Dictionary of Biology Oxford University Press, Oxford, 2012.

32 Young, T., \& Tvedt, M. (2017). "Preface". In Drafting Successful Access and Benefit-sharing Contracts. Leiden, The Netherlands: Brill | Nijhoff, in Chapter 5, at p. 113 sig. 


\subsection{Degree of Exclusivity for the Collector}

Making samples available is a trade-off versus the rights of the collector. Tvedt and Jørem noted "three main alternatives [to exclusivity]: samples are held in trust on behalf of the depositor; samples are given without restriction; samples are pooled under certain specific conditions." ${ }^{33}$ Broggiato et al. call this an "embargo period" where the access by others is restricted for a longer or shorter period of time. ${ }^{34}$

Seemingly the most attractive option from the perspective of incentives to invention is to provide the depositor a period of exclusivity as a main trade-off in accepting an obligation to deposit the samples and other subject matter in the global marine repository. This is a crucial point where the contract with the depositor could open for individually adapted solutions; either by leaving parts open for negotiations or leaving the contract with two or three standard options. Practically, the contract could stipulate three binding options for the depositor to choose from at a later stage. The most important observation is that if these questions are not resolved in the contract prior to collection, it is virtually impossible to impose any obligation on the user when having the material in hand, except from those imposed by national acts. СвD implementation has shown a reluctance by countries to impose a general benefit-sharing obligation in the acts.

In setting up the information-sharing parts of the repositories the system must be designed in a manner that is compatible to other legal systems handling information. The system must reserve publication to a point of time agreed by the depositors. Publication of academic articles is based on a principle of contributing to the state of knowledge. Material or information must be made available to the public in a manner and at a time securing publication possibilities. Patenting a new invention based on the material or information is also assessed from the perspective of the technical patent-law definition of 'prior art' - which means that state of publications that the patent is measured against. Prior art is the baseline against which novelty and inventiveness are assessed. Making a sequence available or publishing sequence data can be regarded as 'prior art' and probably prevent a patent from being granted. This relationship between the system of repositories and other legal systems needs to be clarified. ${ }^{35}$ If the system fails to secure the secrecy until any rights

Tvedt, M. and Jørem, A. "Bioprospecting in the High Seas: Regulatory Options for Benefit Sharing" in Journal of World Intellectual Property 16 (2013) 3-4. pp. 150-167, at p. 157.

34 Broggiato et al. 2018, p. 21-22.

35 Agreement on Trade-Related Aspects of Intellectual Property Rights, adopted on 15 April 1994, article 27(1). There are different understandings of the "novelty" requirement, ranging from an absolute novelty requirement to a local novelty requirement, see 
are secured it would undermine the incentive to deposit material, reduce the incentive to do research or innovation based on the material or information.

\subsection{Conditions for the Use by Others}

The objective of deposits in repositories is to make samples available for other. This does not mean that the material shall be without restrictions on the second users. From the perspective of the collector the conditions for the second user needs to be predictable and take his interests into account. Technically legally, it is not as urgent to set these criteria and conditions in the first contract with the collector before the cruise. However, to strike a balance and ensure the rights of the collector, at least the core topics should preferably be outlined in the first contract.

To compare again with the plant sector, the whole idea of the International Agricultural Research Centres (IARCs) of the Consultative Group on International Agricultural Research (CGIAR) for plants and the whole rationale for the Plant Treaty is that parties other than the depositor shall have access. In this system, the interest of the collector is seldom reflected in the conditions set on the second user. The collections of plant have been instrumental in promoting plant breeding. ${ }^{36}$ The importance to make material available and conserved is the main rationals - less attention has been given to make monetary benefits back to the provider. For the global society to get a similar effect on innovation based on marine biological material, repositories can play a similarly important role. Therefore, the contract needs to clarify and specify the conditions whereby others may use the material. Unlike the plant sector, the collector needs to have incentives in making the samples available through this system. The manner in which the conditions on the second user is formulated has potential to create positive incentives.

The rights of others to apply for patent protection also needs to be specified. Other users need to know the conditions on which they invest in research on these samples. In the case where the second user arrives at a patentable

P.W. Grubb, Patents for Chemicals, Pharmaceuticals and Biotechnology: Fundamentals of Global Law, Practice and Strategy, (Oxford University Press, Oxford, 1999), pp. 54-8.

36 On the history and functioning of the CGIAR, see C. Fowler, and P. Mooney, Shattering: Food, Policies and the Loss of Genetic Diversity, (University of Arizona Press, Tucson, 1990) pp.150-1;FAO (1997) The State of the World's Plant Genetic Resourcesfor Food and Agriculture, FAO, Rome, p. 253; S. Louafi, 'Collective Action Challenges in the Implementation of the Multilateral System of the International Treaty: What Roles for the CGIAR Centres?', in Halewood, M., Noriega, I.L. and Louafi, S. (eds) Crop Plant Genetic Resources As a Global Commons: Challenges in International Law and Governance. (Earthscan, Abington, 2013) pp. 310-28. 
invention, the principle of sharing part benefits of the invention with the original pool would be imperative for an open access system to work. To create a positive incentive for the collector to deposit samples, one could consider to impose a condition on the second user that the collector has a right to a licence of the patented invention when the new invention is based on "his" material. An alternative could be that a small portion of the turnover created by the patent finds it ways back to the collector.

Both mechanisms could be specified in the collection contract as well in the later contract between the collection and the new user. Since these conditions potentially only gives rights to the collector, it is not as urgent that all details are spelled out in the original contract.

\subsection{On the Possibility of Imposing Obligations on Transfer}

A central topic for ABS contracts is the transfer to third parties of any of the material, information or knowledge. ${ }^{37}$ Solutions to this complex contract law question must be resolved in the original contract. Ideally, each of the subject matter elements described in the section above should have its tailor-made transfer solution. In first generation ABS contract, this question was set on hold since it was perceived too complex and the initial agreement postpones how this question shall be regulated till later. However, this approach is not recommendable as at this later stage the negotiation positions are different at the point of time of leaving for a cruise and the situation when a final product has been developed and is ready to be transferred.

Institutional Options

In this model for access and benefit sharing two institutions are needed: (i) the repositories where accessions and other subject matter are kept; and (ii) the institute with competence to represent the common interest in the negotiation of the contract.

As mentioned above the repositories needs to be a global system, but also to be geographically distributed. Since the infrastructure is expensive and much more advanced than for plants building on the existing repositories is probably the only viable solution. For plants a freezer with stable electricity is sufficient to maintain a good part of seed samples. For living organisms, often collected

37 Young, T., \& Tvedt, M. (2017). "Preface”. In Drafting Successful Access and Benefit-sharing Contracts. Leiden, The Netherlands: Brill | Nijhoff., Chapter 6 is devoted to third party transfer in ABS contracts. 
in deep seas, it is far more difficult and costly to conserve the genetic base. Seeds can also be stored for a long time with high percentage of germination. The regeneration of higher organisms is a much more technically complex process. Also bacteria and viri raises their particular challenges.

Here again the flag State jurisdiction can be triggered. The flag State could be required to enter into the contract on behalf of the public and common interest. ${ }^{38}$ Since the nation-state has limited interest in invoking obligations on its own citizens, there must be an obligation in the implementing agreement for them to take the common interest into the negotiations. A contractbased system has its benefits in the flexibility. The same flexibility there is a risk of lessening the burdens for the flag State's own collectors, so there is a clear role for a global body.

Perhaps regional fisheries management organisations or frameworks like the OSPAR Convention ${ }^{39}$ may serve as contracting partners. Nevertheless, the body responsible for the contracts needs standardised templates with a level of discretion to adapt to the individual situation.

Summary of Suggested Solution to the ABs-System

This chapter suggests the use of two main regulatory instruments as tools for making a marine genetic resources pool possible: first, regulating the flag State principle and, second, drafting a comprehensive and clear contract that should be entered into before collection starts. In developing a contract, the terms and conditions should learn from contract law analysis and observe that the SMTA for the Plant Treaty has not succeeded. The contract (or SMTA) must be a valid, binding, implementable and enforceable document. The details in how such a contract could look like is a too comprehensive task for this chapter.

38 UnCLOS, article 92(1), and Pursuant to UNCLOS Article 91 there must nonetheless be a "genuine link between the State and the ship".

39 Convention for the Protection of the Marine Environment of the North-East Atlantic, 2354 UNTs 67, adopted on 22 September 1992. 